\title{
Assessment of Genetic Divergence in Mutant Lines of Tomato (Solanum lycopersicum L.)
}

\author{
Sunday C. Makinde ${ }^{1}$, Regland M. Onyemeka ${ }^{1}$, Opeyemi Oyetunji ${ }^{1}$, Abisola Ogunba ${ }^{1}$ and Muinat Asuni ${ }^{1}$
}

${ }^{1}$ Department of Botany, Faculty of Science, Lagos State University, Nigeria

\section{Correspondence}

Sunday C. O. MAKINDE

E-mail: scmakinde@yahoo.comand olubunmi.makinde@lasu.edu.ng

Telephone: $+234(0) 8033277358$ and $+234(0) 8088494428$

\begin{abstract}
:
Introduction: Mutation breeding is the process of exposing seeds to chemicals or radiation in order to generate mutants with desirable traits.

Aim: This study is aimed at assessing the genetic variability among mutant lines of tomato (Solanum lycopersicum L.) generated from a variety of tomato (Roma VF) using two different chemo-mutagens.

Materials and Method: The collected seeds were exposed to different concentrations of Sodium azide and Colchicine with varied period of exposure. The seeds were planted and selected 49 positive mutant lines were assessed for morphological genetic variability and yield. 18 mutant lines that produced fruits were tagged and selected. The fruits of the selected mutants were harvested and the seeds (M2 seeds) were subsequently planted for divergence analysis. Ten quantitative characters and twenty qualitative characters were scored using IPGRI standard tomato descriptor. The potted experiment was laid out in the Green House, using Randomized Block Design (RBD) with three replications.

Result: The results of this study revealed a high genetic divergence among the mutant lines in both quantitative and qualitative characters. There was significant LSD (0.05) for Germination percentage (7.66), Plant height at maturity (7.05) and Number of leaves at maturity (4.56). The yield (fresh fruit weight) varied significantly, ranging from $10.00 \mathrm{~g}$ for LeMT29 to $319.70 \mathrm{~g}$ for LeMT7 respectively. Fruit and plant qualitative characters equally exhibit variation.

Conclusion: These observations suggest the existence of genetic variability among the different mutant tomato lines. Further selection and field trials is recommended to identify suitable and desirable lines for possible variety release.
\end{abstract}

To Keywords: Mutant, Tomato, Colchicine, Sodium azide, genetic variability. 


\section{INTRODUCTION}

Mutation breeding is the process of exposing seeds to chemicals or radiation in order to generate mutants with desirable traits. From 1930-2007 more than 2,540 mutagenic plant varietals have been released that have been derived either as direct mutants $(70 \%)$ or from their progeny (30\%) [1]. Crop plants account for $75 \%$ of released mutagenic species with the remaining $25 \%$ being ornamentals or decorative plants [2]. In order to speak more clearly about mutations and their potential for crop improvement, it would seem desirable to have different terms at least for (a) the phenotypic alteration and (b) the various underlying molecular and numerical changes. But in any case, a mutation has to be phenotypically expressed to be selectable; all other mutations are only of scientific interest [3]. Mutations are the tools used by the geneticist to study the nature and function of genes which are the building blocks and basis of plant growth and development, thereby producing raw materials for genetic improvement of economic crops [4]. It is a powerful and effective tool in the hands of plant breeders especially for autogamous crops having narrow genetic base $[4,5]$. During the past 70 years, more than 3,222 mutant cultivars from 175 plant species including ornamentals, cereals, oilseeds, pulses, vegetables, fruits and fibers have been officially released in 50 countries all over the World $[1,6,7,8]$.

The cultivated tomato (Solanum lycopersicum L.) is the most popular garden vegetable and is the second most important vegetable crop in the world in terms of consumption per capital $[9,10]$. In 2004, tomato assumed the position of one of the most important fruits in terms of Worlds' vegetable produced [11]. Tomato is grown in almost every corner of the planet. On global basis, it is planted 4.6 million hectares of agricultural lands with a total production of 125.5 million metric tons [12]. Nigeria is the 14th largest producer of tomatoes in the world and second only to Egypt in Africa at 1.51 million metric tons valued at N87 billion ( $\$ 556.1$ million) with a cultivated area of 264,430 ha [13]. Both the wet and dry season cropping system contributes immensely to the national requirement. But the bulk production is from the dry season cropping system grown yearly under irrigation system [14]. Tomato belongs to the Solanaceae family, which includes 3,000 species with origins in both the Old (eggplant in China and India) and New World [15].

Several breeders have studied genetic diversity in tomato germplasm for improvement of various growth and yield related traits $[16,17,18]$ but Nigeria has a narrow tomato genetic base, therefore the main aim of this study was to induce variability in a known genotype of tomato (ROMA VF) using two chemical mutagens (Sodium azide and Colchicine) with the specific objectives of selecting positive mutants, evaluation of the selected mutant lines to determine the extent of genetic variability and identification of promising mutant lines for future trials.

\section{MATERIAL AND METHODS}

Dried seeds of tomato (var. ROMA VF) collected from the Institute of Agriculture Research and Training (IART) Moore Plantation Ibadan, Oyo state, Nigeria was the foundation seed used in this study. Tomato seeds collected were pre-soaked in water for 24 hours. The presoaked seeds were treated with different concentration of Sodium azide $(1.0 \times 10-3 \mathrm{~mol}, 2.5 \times$ $10-3 \mathrm{~mol}$ and $5.0 \times 10-3 \mathrm{~mol})$ and Colchicine $(0.05 \%$ and $0.1 \%$ ) with varied period of exposure (15 min, 30 min and $45 \mathrm{~min}$ ). The treated seeds were planted in rows having 10-plants per row keeping row-to-row and plant-to-plant distances of $60 \mathrm{~cm}$ and $30 \mathrm{~cm}$, respectively with the untreated seeds serving as control.

49 positive mutant lines were identified and tagged as appropriate. The selected 49 positive mutant lines were assessed for morphological genetic variability and yield. The potted experiment was laid out in the greenhouse of the department of Botany, Lagos State University, Ojo Lagos using Randomized Block Design (RBD) with three replications. The blocks contained 10 stands (pots) of each 49 mutant lines, making 30 stands per line (these were the M1 plants). The between and within row spacing of $60 \mathrm{~cm}$ and $30 \mathrm{~cm}$ respectively was maintained. 18 mutant lines that produced fruits were tagged and selected. This is represented in Table 1. The fruits of the selected mutants were harvested and the seeds (M2 seeds) were subsequently planted for divergence analysis.

Ten quantitative characters and twenty qualitative characters were scored for using the standard descriptor for tomato [19]. Quantitative data scored for includes; plant height at maturity, number of leaves per plant etc., while qualitative characters include growth habit, stem pubescence etc. Quantitative data collected was subjected to statistical analysis using the Fisher's Least Significance Difference (LSD) test [20].

\section{RESULTS AND DISCUSSION}

Considerable variation was observed for all studied traits among the mutant lines. Their phenotypic variations were estimated and shown in different tables and figures. The mean, standard deviation and least significant difference (LSD) of the 10 quantitative characters analyzed for the 18 positive mutant lines that produced fruits are presented in Tables 2. A look at Table 2 reveals that the mean yield (fresh fruit) for the 18 mutant lines (M2) ranged from $10.00 \mathrm{~g}$ per plant for LeMT29 to $319.70 \mathrm{~g}$ per plant for LeMT7, the mean plant height at maturity ranged from $46.54 \mathrm{~cm}$ for LeMT11 to $117.72 \mathrm{~cm}$ for LeMT49. The average number of nodes at maturity also ranged from 1.20 for LeMT27 and LeMT47 to 5.25in LeMT49.

The qualitative characters of Roma VF (control) and the 18 positive mutant lines are presented in Table 3 . There was high level of diversity in some characters such as fruit shape, growth habit, stem pubescence, folia density, leaf altitude and degree of leaf dissection. The 
fruit shape of Roma VF (control) is highly rounded. However, the mutagens had effect on the gene(s) controlling fruit shape leading to high level of diversity observed in fruit shape from high rounded in Roma VF to pointed, cylindrical, heart shape, pyriform, slightly flattened and rounded observed in the mutants. The leaf colour, colour of immature fruit and fruit shoulder shape exhibit moderate level of diversity among the mutant lines against the control. While shape of pistil scar, fruit radial cracking and fruit cross-sectional shape exhibited low level of diversity among the mutants against the control.

Figure 1 is a graphical representation of plant height at maturity among the 18 selected mutant lines against the control. Figure 2 is graphical expression of yield per plant among the 18 positive mutant lines against the control. Closer look at figure 1 and 2 revealed variation among the selected mutant lines as well as from the control (Roma VF) used in the study. LeMT7 had the highest yield $(319.7 \mathrm{~g})$, followed by LeMT49 (240g), LeMT39 (187.75g), LeMT11 (155.8g) and LeMT2 $(130.12 \mathrm{~g})$ as against the Roma VF (control) with yield of 125.15g. LeMT28 and LeMT29 had the lowest yield of $10.80 \mathrm{~g}$ and $10.00 \mathrm{~g}$ respectively.

\section{DISCUSSION}

The results of this study indicate a high genetic divergence among the mutant lines against the control in both quantitative and qualitative characters. There was significant difference for germination percentage, plant height and number of leaves among the mutant lines. The yield varied significantly among the positive mutant lines. The highly significant differences observed using Fisher's least significant difference (LSD) [20] for Germination percentage, Plant height at flowering and number of leaves at flowering among the genotypes evaluated was indication of great deal of variability with respect to these characters. In the same vain, the observed significant variation in the yield among the 18 positive mutant lines also supports the earlier claim that there is a great deal of variability among the genotypes. The observed divergence among the positive mutant lines in reference to both quantitative and qualitative characters was in line with the work of [4] on tomato using Sodium azide and it further confirms that generally, Sodium azide and colchicine are very effective in inducing mutations in tomato. A thorough analysis on quantification of phenotypic variation due to mutagenic effect has also been reported in chickpea [21].

Fruit weight is a quantitatively inherited character that is controlled by many genetic loci; some may have a large effect while others have small effect [22, 23, 24]. High fruit weights observed may be as a result of the effect of the mutagens on the allele fw 2.2 which influences fruit weight [25]. This allele acts as a regulator of cell division in larger size fruits of tomato [26]. The differences in fruit size observed may be due to the regulators of cell division and cell size acting after anthesis [27].
No significance effect was observed in this population of tomato for number of branches per plant, number of nodes, leaf blade length, and petiole length and as such these characters cannot be used for selection in subsequent improvement program. This observation was consistent with earlier reports by Adamu et al. [28, 29] on mutagenic study on groundnut and tomato using gamma rays and that of Sheeba et al. [30] using gammar rays and EMS on Sesanum indicum further confirms that the effects of mutagens on these traits were dose dependent.

There was wide array of variations observed in respect of fruit and plant qualitative characters. The variations were easily recognizable with visual observation. These variations may be as a result of the effect of the mutagens used in this study on the alleles controlling these characters.

\section{CONCLUSION}

In conclusion, this study has shown that variation can be easily induced in crop plant using chemical mutagens such as Colchicine and Sodium azide. The level of variation observed after treatment buttress the earlier claim that mutation can raw materials for genetic improvement of economic crops. A number of the positive mutants selected perform better than the original variety (Roma VF).

The following selected positive mutants LeMT7, LeMT49, LeMT39 and LeMT11 has been identified as good lines that can form basis for subsequent improvement program in tomato. Subsequent evaluation can further screen these lines with view to releasing them as a new variety.

\section{ACKNOWLEDGEMENTS}

The authors acknowledge the invaluable inputs of the anonymous reviewers whose contributions gave rise to this paper.

\section{COMPETING INTERESTS}

We declare that there are no competing interests with anyone on this research work and the manuscript.

\section{AUTHORS' CONTRIBUTIONS}

Sunday C. Makinde, Regland M. Onyemeka and Opeyemi Oyetunji designed the study. Regland $\mathrm{M}$. Onyemeka performed the statistical analysis, managed the literature searches and wrote the first draft of the manuscript. Sunday C. Makinde, Opeyemi Oyetunji, Abisola Ogunba and Muinat Asuni reviewed the first draft before submission. 
Table 1: Selected 18 mutant lines (M2) and their coding

\begin{tabular}{|c|c|c|}
\hline Serial Number & Lines & TREATMENTS \\
\hline 1 & LeMT1 & $\mathrm{NaN}_{3}\left(1.0 \times 10^{-3}\right) / 15 \mathrm{~min}$ \\
\hline 2 & LeMT2 & $\mathrm{NaN}_{3}\left(1.0 \times 10^{-3}\right) / 15 \mathrm{~min}$ \\
\hline 3 & LeMT6 & $\mathrm{NaN}_{3}\left(1.0 \times 10^{-3}\right) / 45 \mathrm{~min}$ \\
\hline 4 & LeMT7 & $\mathrm{NaN}_{3}\left(2.5 \times 10^{-3}\right) / 15 \mathrm{~min}$ \\
\hline 5 & LeMT10 & $\mathrm{NaN}_{3}\left(2.5 \times 10^{-3}\right) / 15 \mathrm{~min}$ \\
\hline 6 & LeMT11 & $\mathrm{NaN}_{3}\left(2.5 \times 10^{-3}\right) 30 \mathrm{~min}$ \\
\hline 7 & LeMT23 & $\mathrm{NaN}_{3}\left(5.0 \times 10^{-3}\right) / 30 \mathrm{~min}$ \\
\hline 8 & LeMT24 & $\mathrm{NaN}_{3}\left(5.0 \times 10^{-3}\right) / 30 \mathrm{~min}$ \\
\hline 9 & LeMT25 & $\mathrm{NaN}_{3}\left(5.0 \times 10^{-3}\right) / 45 \mathrm{~min}$ \\
\hline 10 & LeMT26 & $\mathrm{NaN}_{3}\left(5.0 \times 10^{-3}\right) / 45 \mathrm{~min}$ \\
\hline 11 & LeMT27 & $\mathrm{NaN}_{3}\left(5.0 \times 10^{-3}\right) / 45 \mathrm{~min}$ \\
\hline 12 & LeMT28 & $\mathrm{NaN}_{3}\left(5.0 \times 10^{-3}\right) / 45 \mathrm{~min}$ \\
\hline 13 & LeMT29 & Colchicine $(0.1 \%) / 15 \mathrm{~min}$ \\
\hline 14 & LeMT30 & Colchicine $(0.1 \%) / 15 \mathrm{~min}$ \\
\hline 15 & LeMT33 & Colchicine $(0.1 \%) / 30 \mathrm{~min}$ \\
\hline 16 & LeMT39 & Colchicine $(0.1 \%) / 45 \mathrm{~min}$ \\
\hline 17 & LeMT47 & Colchicine $(0.05 \%) / 45 \mathrm{~min}$ \\
\hline 18 & LeMT49 & Colchicine $(0.05 \%) / 45 \mathrm{~min}$ \\
\hline
\end{tabular}


Table 2: Population means, SD and LSD for quantitative characters of the control and 18 positive mutant lines of Tomato (Solanum lycopersicum).

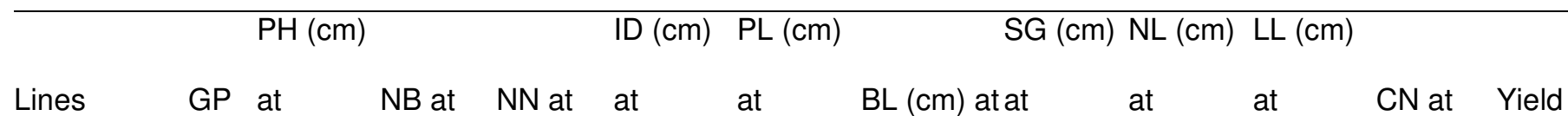

(\%) maturity maturity maturity maturity maturity maturity maturity maturity maturity maturity $(\mathrm{g})$

\begin{tabular}{|c|c|c|c|c|c|c|c|c|c|c|c|c|}
\hline \multicolumn{13}{|l|}{ Control } \\
\hline \multicolumn{3}{|c|}{ (Roma VF) 100.0052 .40} & \multirow{2}{*}{$\begin{array}{l}5.00 \\
2.40\end{array}$} & \multirow{2}{*}{$\begin{array}{l}20.20 \\
15.00\end{array}$} & \multirow{2}{*}{$\begin{array}{l}4.98 \\
4.38\end{array}$} & \multirow{2}{*}{$\begin{array}{l}6.34 \\
4.98\end{array}$} & \multicolumn{2}{|c|}{27.602 .56} & 16.20 & 19.08 & 5.00 & 125.15 \\
\hline LeMT1 & 90.00 & 71.32 & & & & & 19.82 & 2.98 & 25.20 & 22.26 & 5.00 & 106.06 \\
\hline LeMT2 & 90.00 & 54.56 & 1.40 & 14.60 & 3.68 & 4.80 & 14.80 & 2.74 & 18.80 & 21.64 & 5.00 & 130.12 \\
\hline LeMT6 & 80.00 & 69.68 & 3.20 & 20.60 & 4.72 & 7.02 & 17.40 & 3.24 & 34.20 & 24.38 & 5.00 & 22.96 \\
\hline LeMT7 & 70.00 & 78.78 & 3.00 & 16.80 & 5.08 & 5.48 & 20.46 & 3.32 & 32.60 & 24.30 & 5.00 & 319.70 \\
\hline LeMT10 & 90.00 & 50.52 & 5.00 & 13.40 & 3.46 & 4.87 & 14.48 & 2.76 & 17.00 & 18.80 & 5.00 & 92.97 \\
\hline LeMT11 & 65.00 & 46.54 & 2.00 & 14.00 & 4.26 & 3.90 & 10.66 & 2.44 & 18.00 & 15.34 & 5.00 & 155.80 \\
\hline LeMT23 & 55.00 & 80.68 & 3.50 & 18.50 & 3.35 & 5.00 & 17.93 & 3.03 & 24.75 & 23.24 & 5.00 & 37.94 \\
\hline LeMT24 & 65.00 & 111.74 & 4.40 & 25.00 & 3.30 & 6.74 & 13.54 & 3.26 & 50.40 & 24.48 & 5.00 & 23.00 \\
\hline LeMT25 & 25.00 & 88.80 & 4.00 & 18.50 & 4.28 & 6.23 & 16.33 & 3.28 & 39.25 & 23.78 & 6.00 & 13.72 \\
\hline LeMT26 & 50.00 & 83.34 & 1.80 & 17.80 & 4.68 & 6.02 & 20.42 & 3.10 & 31.20 & 19.07 & 5.00 & 50.10 \\
\hline LeMT27 & 55.00 & 73.32 & 1.20 & 15.40 & 4.50 & 5.26 & 13.90 & 3.26 & 16.60 & 21.02 & 5.00 & 110.00 \\
\hline LeMT28 & 55.00 & 72.66 & 2.00 & 14.60 & 6.78 & 5.82 & 19.66 & 3.18 & 20.00 & 24.39 & 5.00 & 10.50 \\
\hline LeMT29 & 60.00 & 67.15 & 1.25 & 13.75 & 3.65 & 5.85 & 13.73 & 2.90 & 19.75 & 17.17 & 5.00 & 10.00 \\
\hline LeMT30 & 55.00 & 62.82 & 2.40 & 14.80 & 4.62 & 5.74 & 14.86 & 3.30 & 21.80 & 19.01 & 5.00 & 12.49 \\
\hline LeMT33 & 90.00 & 92.04 & 5.00 & 22.60 & 4.40 & 4.84 & 11.32 & 3.14 & 42.20 & 19.18 & 6.00 & 57.00 \\
\hline LeMT39 & 80.00 & 57.36 & 2.00 & 15.60 & 6.40 & 3.64 & 14.28 & 2.94 & 20.40 & 18.35 & 5.00 & 187.75 \\
\hline LeMT47 & 75.00 & 71.82 & 1.20 & 19.00 & 4.44 & 4.74 & 15.06 & 2.86 & 20.40 & 19.00 & 5.00 & 83.72 \\
\hline LeMT49 & 80.00 & 117.72 & 5.25 & 26.25 & 5.60 & 4.73 & 15.58 & 12.70 & 51.50 & 21.23 & 5.00 & 240.00 \\
\hline Mean & 68.33 & 75.05 & 2.83 & 17.57 & 4.53 & 5.31 & 15.79 & 3.58 & 28.00 & 20.92 & 5.11 & 92.44 \\
\hline SD & 17.74 & 19.07 & 1.39 & 3.87 & 0.96 & 0.89 & 2.95 & 2.29 & 11.36 & 2.81 & 0.32 & 87.54 \\
\hline $\operatorname{LSD}(0.05)$ & $12.48^{*}$ & * $13.41^{*}$ & 0.98 & 2.72 & 0.68 & 0.62 & 2.07 & 1.61 & 7.99 & $12.48^{*}$ & 1.98 & $61.7^{*}$ \\
\hline
\end{tabular}

${ }^{*}=$ Significant LSD (0.05)

Quantitative characters scored for in this study, how they are scored and unit of measurement 


\begin{tabular}{|ll}
\hline NB = Number of Branches/ plant at & NB = Number of Branches/ plant at \\
maturity (determined by counting) & maturity (determined by counting) \\
GP = Germination Percentage (\%) & $\begin{array}{l}\mathrm{NN}=\text { Number of Nodes/ plant at } \\
\text { maturity (determined by counting) }\end{array}$ \\
$\begin{array}{ll}\mathrm{PH}=\text { Plant Height at maturity } \\
\text { fourth to seventh internodes) }(\mathrm{cm})\end{array}$ & $\begin{array}{l}\text { (measured from the base to stem } \\
\text { apex) (cm) }\end{array}$ \\
$\begin{array}{ll}\mathrm{LL}=\text { Total Leave Length (measured } \\
\text { from the base of petiole to leaf apex) }\end{array}$ & $\begin{array}{l}\text { leaves on fourth to seventh nodes) } \\
\text { (cm) }\end{array}$ \\
$\begin{array}{l}\text { (cm) } \\
\text { LN = Number of Leaves/ plant }\end{array}$ & SG = Stem Girth at maturity \\
(determined by counting) & (measured on the ground level) $(\mathrm{cm})$
\end{tabular}

Table 3: Qualitative characteristics of the 18 positive mutant lines of Tomato (Solanum lycopersicum)

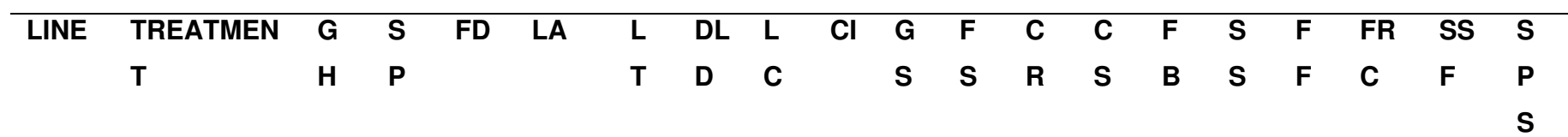

\begin{tabular}{|c|c|c|c|c|c|c|c|c|c|c|c|c|c|c|c|c|c|c|c|}
\hline \multirow{3}{*}{$\begin{array}{l}\text { Rom } \\
\text { a VF }\end{array}$} & Control & 3 & 5 & 5 & 7 & 2 & 5 & 2 & 3 & 0 & 4 & 5 & 1 & 2 & 3 & 1 & 0 & 5 & 2 \\
\hline & & & & & & & & & & & & & & & & & & & \\
\hline & $\mathrm{NaN}_{3}(1.0 \times$ & 3 & 5 & 5 & 3 & 3 & 5 & 4 & 3 & 0 & 6 & 5 & 1 & 3 & 3 & 1 & 0 & 1 & 2 \\
\hline & $\left.10^{-3}\right) / 15 \mathrm{~min}$ & & & & & & & & & & & & & & & & & & \\
\hline
\end{tabular}

$\mathrm{T} 1$

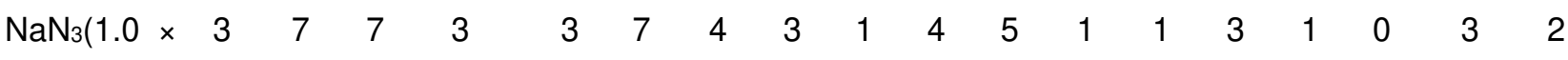

LeM $\left.10^{-3}\right) / 15 \mathrm{~min}$

T2

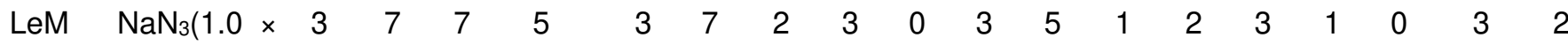

T6 $\left.10^{-3}\right) / 45 \min$

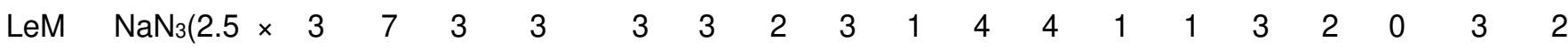

T7 10 $\left.10^{-3}\right) 15 \mathrm{~min}$

$\begin{array}{llllllllllllllllllll}\text { LeM } & \mathrm{NaN}_{3}(2.5 \times & 3 & 7 & 7 & 7 & 3 & 7 & 2 & 5 & 1 & 6 & 4 & 1 & 1 & 3 & 1 & 1 & 3 & 4\end{array}$

T10 10 $\left.10^{-3}\right) 15 \mathrm{~min}$

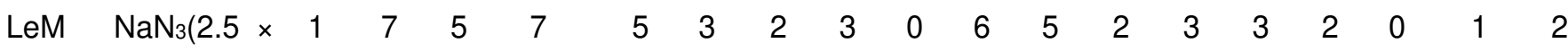

T11 $\left.10^{-3}\right) 30 \mathrm{~min}$

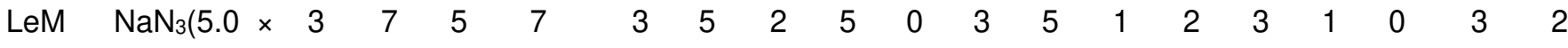

T23 10 $\left.10^{-3}\right) 30 \mathrm{~min}$ 


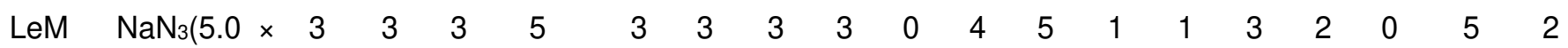

T24 10-3)30min

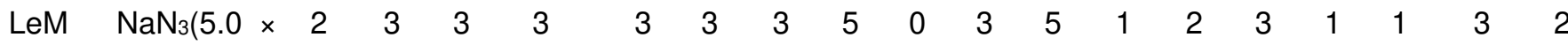

T25 $\left.10^{-3}\right) 45 \mathrm{~min}$

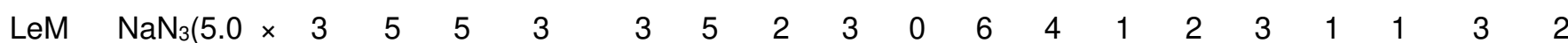

T26 10 $\left.10^{-3}\right) 45 \mathrm{~min}$

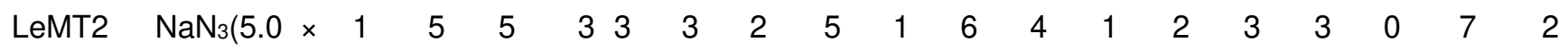

$\left.7 \quad 10^{-3}\right) / 45 \mathrm{~min}$

$\begin{array}{llllllllllllllllllllllll}\text { LeMT2 } & \mathrm{NaN}_{3}(5.0 \times & 3 & 7 & 3 & 5 & 3 & 5 & 2 & 3 & 0 & 6 & 4 & 1 & 3 & 3 & 2 & 0 & 3 & 2\end{array}$

$\left.8 \quad 10^{-3}\right) / 45 \mathrm{~min}$

LeMT2 $\quad$ Colchicine $\left(\begin{array}{llllllllllllllllllll}1 & 5 & 3 & 7 & 3 & 5 & 2 & 5 & 1 & 6 & 4 & 1 & 3 & 3 & 1 & 0 & 1 & 2\end{array}\right.$ $90.1 \%$

$15 \mathrm{~min}$

$\begin{array}{llllllllllllllllllllllll}\text { LeMT3 } & \text { Colchicine } & 3 & 7 & 3 & 7 & 3 & 7 & 1 & 3 & 0 & 5 & 5 & 1 & 3 & 3 & 5 & 0 & 7 & 2\end{array}$ $0 \quad(0.1 \%)$

$15 \min$

$\begin{array}{lllllllllllllllllllllll}\text { LeMT3 } & \text { Colchicine } & 3 & 3 & 7 & 7 & 3 & 7 & 2 & 7 & 1 & 3 & 5 & 1 & 2 & 3 & 1 & 1 & 1 & 2\end{array}$ $3 \quad(0.1 \%)$

$30 \mathrm{~min}$

$\begin{array}{llllllllllllllllllllllll}\text { LeMT3 } & \text { Colchicine } & 3 & 7 & 7 & 3 & 6 & 5 & 2 & 5 & 1 & 2 & 4 & 2 & 2 & 3 & 1 & 0 & 3 & 2\end{array}$ $9 \quad(0.1 \%)$

$45 \min$

$\begin{array}{llllllllllllllllllllll}\text { LeMT4 } & \text { Colchicine } & 2 & 3 & 3 & 3 & 1 & 3 & 2 & 3 & 0 & 6 & 4 & 2 & 3 & 3 & 1 & 0 & 1 & 2\end{array}$ $7 \quad(0.05 \%)$

$45 \min$

$\begin{array}{lllllllllllllllllllll}\text { LeMT4 } & \text { Colchicine } & 1 & 3 & 3 & 3 & 3 & 3 & 2 & 3 & 0 & 7 & 4 & 2 & 1 & 3 & 1 & 1 & 3 & 2\end{array}$ $9 \quad(0.05 \%)$

$45 \mathrm{~min}$

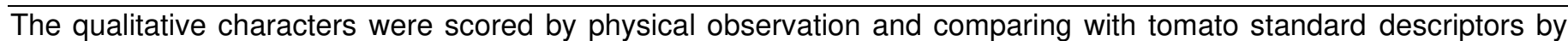
ipgri, 1996 
$\mathrm{Cl}=$ Colour of Immature Fruit

$\mathrm{GH}=$ Growth Habit

$\mathrm{CR}=$ Colour of Ripe Fruit

GS $=$ Green Shoulder

$C S=$ Fruit Cross-Sectional Shape

$\mathrm{LA}=$ Leaf Altitude

$\mathrm{DLD}=$ Degree of Leaf Dissection

$\mathrm{LC}=$ Leaf Colour

$\mathrm{FB}=$ Fruit Blossom End Shape

$\mathrm{LT}=$ Leaf Type

$\mathrm{FC}=$ Fruit Cracking

SSF $=$ Shoulder Shape of Fruit

$\mathrm{FD}=$ Foliage Density

$\mathrm{SP}=$ Stem Pubescence

$F F=$ Fruit Feature

SPS $=$ Shape of Pistil Scar

$\mathrm{FRC}=$ Fruit Radial Cracking

SS $=$ Seed Shape

FS = Fruit Shape

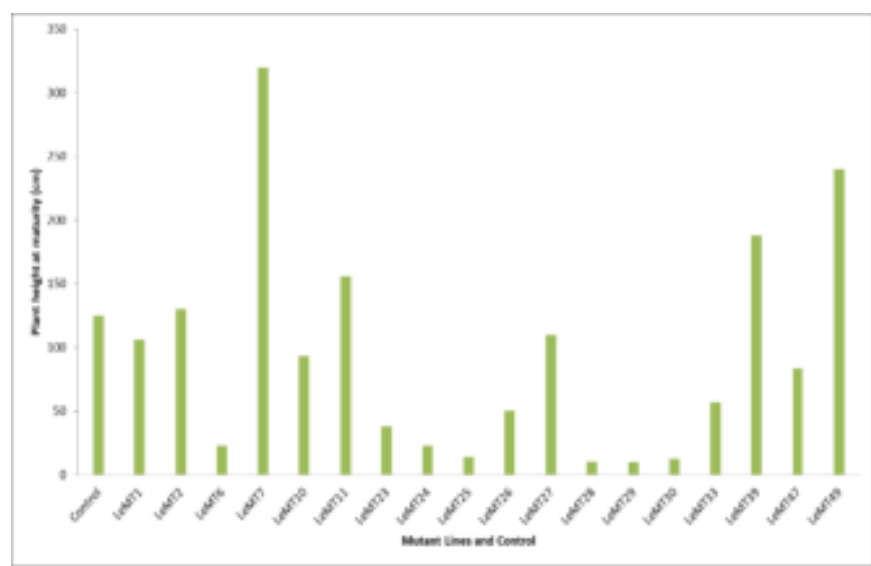

Figure 1: bar chart comparing plant height of control and the 18 positive mutant lines of tomato (solanum lycopersicum).

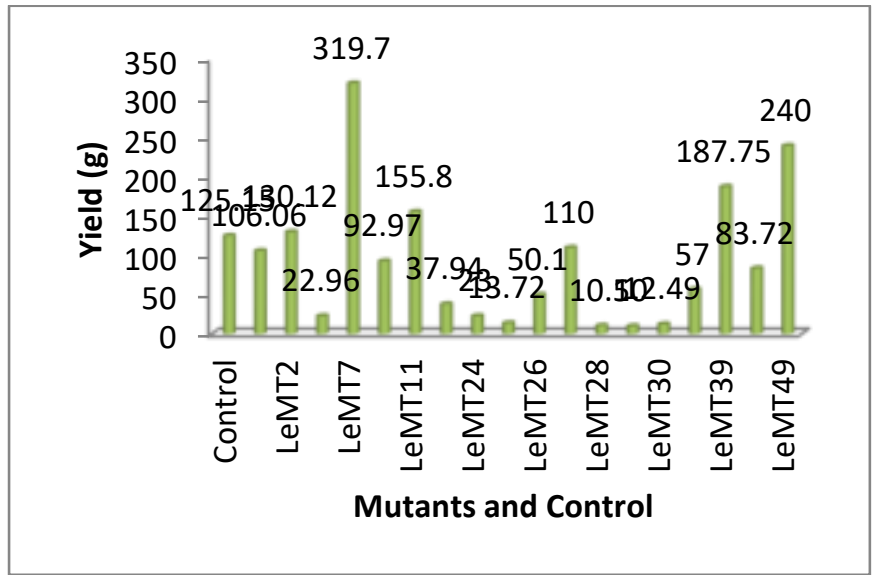

Figure 2: bar chart comparing yield of the control and 18 positive mutant lines of tomato (solanum lycopersicum 


\section{REFERENCES}

1. Maluszynsk, M.K., K. Nichterlein, L. Van Zanten and B.S. Ahloowalia, (2000). "Officially released mutant varieties - the FAO/IAEA Database". Mutation Breeding Review, 12: 1-84.

2. Ahloowali, B.S., (2004). "Global impact of mutation-derived varieties". Euphytica 135: 187204.

3. Bahar A. S and K. Samiullah, (1999). "Breeding in Crop Plants: Mutations \& In Vitro Mutation Breeding"; Kalyani Publishers, Ludhiana (India), p. 1-19.

4. Adamu, A.K. and H. Aliyu, (2007). Morphological effects of sodium azide on tomato (Lycopersicon esculentum Mill). Sci. World J., 2(4): 9-12.

5. Micke, A., M. Maluszynski and B. Donini, (1985). Plant cultivars derived from mutation induction or the use of induced mutants in cross-breeding. Mutation. Breed. Rev., 3: 81-92.

6. Mashenkov, A., (1986): Induced mutation process as a source of new mutants. Maize genetics Cooperation Newsletter, 60: 70-71.

7. Chopra, V.L., (2005). Mutagenesis: Investigating the process and processing the outcome for crop improvement. Curr. Sci., 89(2): 353-359.

8. Scossiroli, R.E., (1977). Mutations in Characters with Continuous Variation. In: Manual on Mutation Breeding, IAEA (Ed.). 2nd Edn., International Atomic Energy Agency, Vienna, Austria, p: 118-123.

9. Khurram, Z., Muhammad, A., Amir, S., Maryam, A and S. Asif, (2016). Assessment of genetic diversity in tomato for fruit morphology, composition and yield. Pak. J. Bot., 48(6): 24772483.

10. Nitish Kumar1, M.L., Bhardwaj1, A.S and K. Nimit, (2017). Assessment of Genetic Divergence in Tomato (Solanum lycopersicum L.) through Clustering and Principal Component Analysis under Mid Hills Conditions of Himachal
Pradesh, India. Int. J. of Curr. Microbiol. and App. Sci 6(5): 1811-1819.

11. FAO (Food and Agricultural Organization), (2005). Food and Agricultural Organisation Production year book. Rome, Italy.

12. FAOSTAT, (2008). Tomato statistics. Available at: http://www.faostat.fao.org

13. CBN (Central Bank of Nigeria), (2013). Nigeria spends 11.7 billion naira on tomato imports. www.sunnewsonline.com

14. Ojo, M.A, Ibrahim O.A and U. S. Mohammed, (2009). Profitability and production function of small scale irrigated tomato production in Niger state, Nigeria. Continental J. Agricultural Economics, 3: 16 - 22.

15. Knapp, S., (2002). Tobacco to tomatoes: a phylogenetic perspective on fruit diversity in the Solanaceae. Journal of Experimental Botany, 53: 2001-2022.

16. El-Awady, M.A.M., A.A.E. El-Tarras and M. Hassan, (2012). Genetic diversity and DNA fingerprint study in tomato (Solanum lycopersicum L.) cultivars grown in Egypt using simple sequence repeats (SSR) markers. Afr. J. Biotech., 11(96): 16233-16240.

17. lqbal, Q., M.Y. Saleem, A. Hameed and M. Asghar, (2014). Assessment of genetic divergence in tomato genotypes by agglomerative hierarchical clustering and principal component analysis. Pak. J. Bot., 46(5): 1865-1870.

18. Saleem, M.Y., M. Asghar and Q. lqbal, (2015). Analysis of genetic proximity in tomato (Solanum lycopersicum L.) genotypes. J. Environ. Agric. Sci., 3: 8-13.

19. IPGRI [International Plant Genetic Resources Institute], (1996). Descriptors for tomato (Lycopersicon spp). IPGRI, Rome, Italy.

20. Gomez, K.A. and A.A. Gomez, (1984). "Statistical Procedure for Agricultural Research". John Wiley and Sons. Inc, New York. pp. 67-215.

21. Laskar, R.A., Khan, S., Khursheed, S., Raina, A., and R., Amin, (2015). Quantitative analysis of induced phenotypic diversity in chickpea using physical and chemical mutagenesis. J. Agron. 14(3), 102-111.

22. Ben-Chaim, A., Borovsky, Y., Rao, G. U., Gur, A., Zamir, D., and I. Paran, (2006). Comparative QTL mapping of fruit size and shape in tomato and 
pepper. Israel Journal of Plant Science, 54: 191203.

23. Doganlar, S., Frary, A., Daunay, M. C., Lester, R. N., and S. D. Tanksley, (2002). Conservation of gene function in the Solanaceae as revealed by comparative mapping of domestication triats in egg plant. Genetics, 161: 1713-1726.

24. Grandillo, S., Ku, H. M., and Tanksley, S. D. (1999). Identifying the loci responsible for natural variation in fruit size and shape in tomato. Theoretical and Applied Genetics, 99: 978-987.

25. Frary, A., Nesbitt, T. C., Frary, A., Grandillo, S., van der Knaap, E., Cong, B., et al., (2000). Cloning and transgenic expression of fw2.2: a quantitative trait locus key to the evolution of tomato fruit. Science, 289 : 85-87.

26. Nunoo, E.K., Quartey, H.M., Amoatey, G.Y.P. $\mathrm{Klu}$, (2014). Effect of recurrent irradiation on the improvement of a variant line of wild tomato (Solanum pimpinellifolium). Journal of Radiation Research and applied Science, 7: 3 7 7-3 83.

27. Paran, I., \& E. Van der Knaap, (2007). Genetic and molecular regulation of fruit and plant domestication traits in tomato and pepper. Journal of Experimental Botany, 58(14), 38413852.

28. Adamu, A. K., Clung, S. S. and S. Abubakar, (2004). Effects of ionizing radiation (gammarays) on Tomato (Lycopersicon esculentum L.). Nigeria Journal of Experimental and Applied Biology, 5(2): 185-193.

29. Adamu, A. K., Oluranju, P. E., Bate, J. A. and O. T. Ogunlade, (2002). Radiosensitivity and effective dose determination in groundnut (Arachis hypogaea L.) irradiated with gammarays. Journal Agriculture and Environment, 3(1): 17-84.

30. Sheeba, A., Abumalarmalhi, J., Babu, S. \& Ibrahim, S. M., (2005). Mutagenic effects of gamma rays and EMS in M1 generation in sesame. Resources on Crops, 6(2): 300-306.

31. Hanson, P., (2005). Lecture Notes on Tomato Breeding. Asian Vegetable Research and Development Center Africa Regional Program Training, Arusha, Tanzania.

32. Agong, S.G., S. Schittenhelm, and W. Fried, (1997). Assessment of salt tolerance in the Kenyan tomato germplasm. Euphytica 95:57-66 [cited in Rahmani, G., (2011). Characterization and inheritance studies of Desirable attributes in tomato. $\mathrm{PhD}$ thesis, department of plant breeding and genetics, faculty of crop production sciences Khyber Pukhtunkhawa Agricultural University Peshawar, Pakistan 
